\title{
РАСПРЕДЕЛЕНИЕ ПОПУТНОГО ЗОЛОТА В ТИТАН-ЦИРКОНИЕВЫХ ПЕСКАХ РОССЫПИ «ЦЕНТРАЛЬНАЯ» (ТАМБОВСКАЯ ОБЛАСТЬ)
}

\author{
С. В. Бондаренко, Г. С. Золотарева
}

Воронежский государственный университет

Поступила в редакцию: 7 июня 2018 г.

\begin{abstract}
Аннотация: в результате изучения титан-циркониевых песков россыпи Центральная комплексом методов установлено крайне неравномерное спорадическое распространение благородного металла в продуктивной толще. По данным пробирно-атомно-адсорбционного анализа его содержание в продуктах обогащения менее 0,01 г/m. Золото тонкое (до 0,1 мм) и ультратонкое (менее 0,1 мм), морфология разнообразна. Наибольшее количество знаков соответствует фракции 0,05+0,03 мм. Крупные чешуйки золота имеют тонкую глинистую пленку, свидетельствуюшую об их консервачии от механического воздействия в процессе переноса. Для более мелких и тонких классов наблюдается высокая очищенность золота. Наиболее часто знаки золота отмечаются $в$ продуктивных песках с относительно высоким содержанием глинистой фракции. Крайне низкие содержания благородного металла и плохая извлекаемость его гравитационными методами указывают на невысокие перспективы попутного извлечения золота из титан-циркониевых песков. Ключевые слова: титан-ц̧иркониевые россыпи, попутное золото, ресурсный потенциал, рентабельность освоения.
\end{abstract}

\section{ASSOCIATED GOLD IN TITANIUM ZIRCONIUM SANDS PLACER «CENTRAL» (TAMBOV REGION)}

\begin{abstract}
As a result of the study of titanium-zirconium sand placer Central set of methods found extremely uneven sporadic distribution of noble metal in the productive thickness. According to the assay-atomic-adsorption analysis of its content in enrichment products less than 0,01 g/t. Gold is thin (up to 0,1 mm) and ultra-thin (less than 0,1 mm), the morphology is varied. The largest number of characters corresponds to the fraction $-0,05+0,03 \mathrm{~mm}$. Large scales of gold have a thin clay shell, indicating their preservation from mechanical impact in the process of transfer. For smaller and thinner classes, high purity of gold is observed. Most often, gold marks are noted in productive sands with a relatively high content of clay fraction. Very low contents of the noble metal and poor recoverability by its gravitational methods indicate low prospects for the associated extraction of gold from titaniumzirconium sands.
\end{abstract}

Key words: mitanium-zirconium placers, associated gold, resource potential, profitability of development.

\section{Введение}

В настоящее время в России одним из важнейших вопросов рационального природопользования является перевод известных нерентабельных геологических объектов в инвестиционно-привлекательные. Эта проблема актуальна для древних погребенных титан-циркониевых россыпей, в том числе приуроченных к территории Тамбовского россыпного района, где размещается один из крупнейших россыпных титан-циркониевых объектов - месторождение «Центральное» (рис. 1). Специалистами по изучению россыпей [1-10] было установлено, что освоение объектов данного типа может быть рентабельным только в случае реализации значительного объема попутной нерудной продукции. В качестве последней для месторождения «Центральное» могут выступать фосфоритовый, глауконитовый, гранатовый, дистен-силлиманитовый, кварцевый продукты. Кроме нерудного сырья в качестве попутного компонента рассматривается и золото, однако целесообразность его извлечения далеко неоднозначна. Предлагаемая статья посвящена изучению распределения золота в песках титан-циркониевой россыпи «Центральная».

В рамках Государственного контракта с Федеральным агентством по недропользованию в период 2012-2014 гг. были выполнены работы, ориентированные на повышение инвестиционной привлекательности месторождения «Центральное». Одним из аспектов данных исследований стало изучение содержания и распределения свободного золота в титанциркониевых песках из-за неоднозначности результатов ранее проведенных производственных работ, изложенных в [1]. 


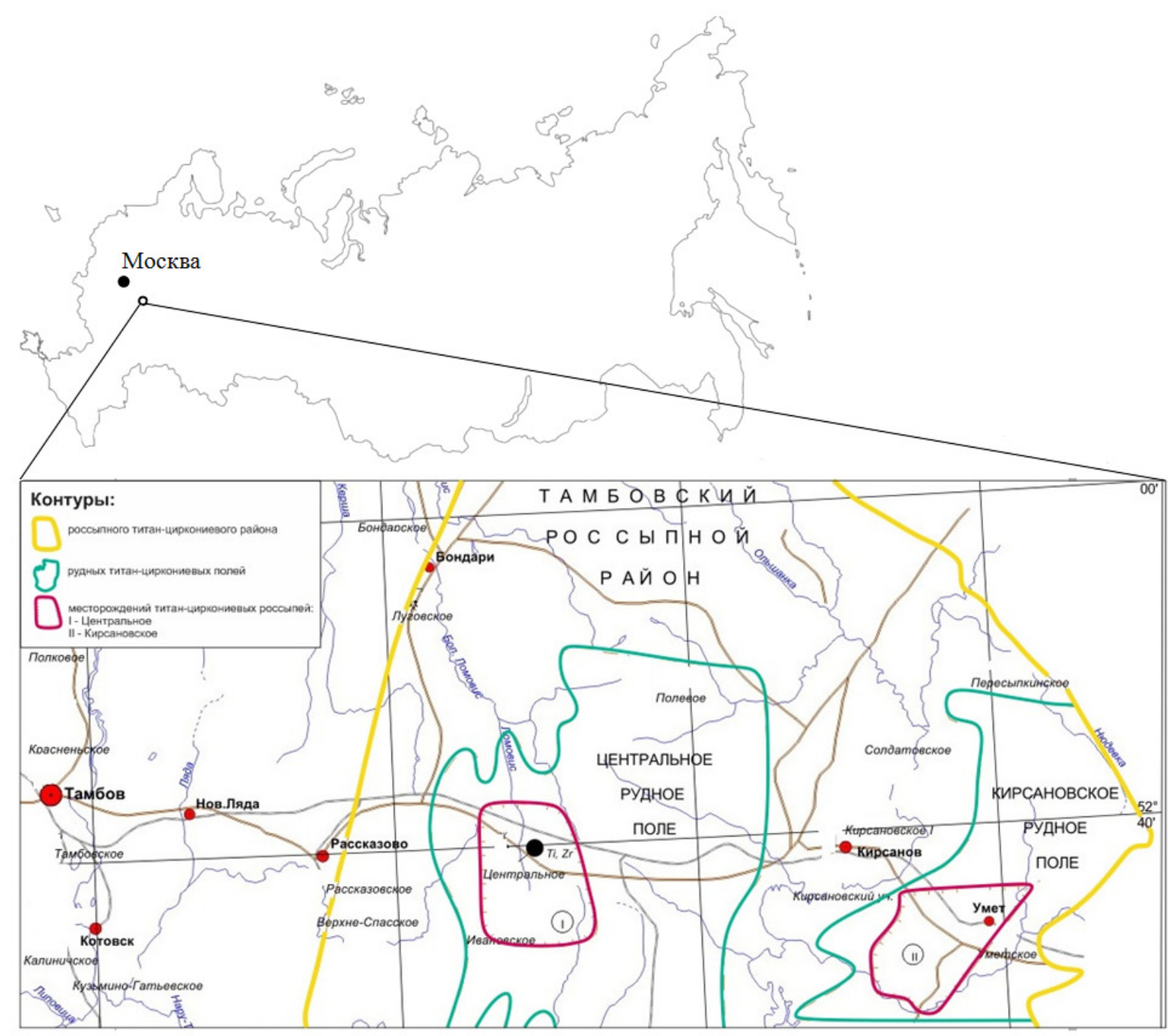

Puc. 1. Схема расположения Центрального месторождения. (Тамбовская область).

\section{Методика и результаты опытно-методических исследований}

Специальные исследования, ориентированные на изучение распределения и извлечения золота и золотосодержащего концентрата включали в себя следующие виды работ: 1) предварительное изучение уровня содержания золота и его распределения в исходном материале, глинистой фракции и фосфоритах по рядовым пробам с помощью приближенно-количественного спектрального анализа на золото; 2) проведение опытно-методических работ по извлечению видимого золота на малообъемной обогатительной установке УОМ-2 из валовых проб кустовых скважин; 3) проведение опытно-методических работ по извлечению видимого золота на центробежном вибрационном концентраторе ЦВК 100-2М из валовых проб кустовых скважин; 4) подтверждение достоверности результатов опытно-методических работ пробирным и пробирно-атомно-адсорбционным анализами.

Приближенно-количественный спектральный анализа на золото выполнен для 354 проб исходных песков, 59 проб фосфоритов и 44 проб глинистой фрак- ции в лаборатории химико-технологических исследований ОАО «Тульское НИГП» (г. Тула, ответственный исполнитель Ю. К. Бирюков). Пробирный анализ (80 концентратов валовых проб) и пробирно-атомноадсорбционный анализ (273 концентрата валовых проб) выполнялись в лаборатории пробирного анализа ФГУП ЦНИГРИ (г. Москва, ответственный исполнитель Т. В. Пучкова).

Опытно-методические работы выполнялись по рядовым и большеобъемным пробам, полученным в результате колонкового бурения одиночных и кустовых скважин (4-10 стволов) в пределах Восточного фланга Центрального месторождения.

Результаты изучения содержания и характера распределения золота в исходном материале, глинистой фракции и фосфоритах по рядовым пробам с помощьью приближенно-количественного спектрального анализа на золото

Приближенно-количественный спектральный анализ на золото (СЗМ), обладающий высокой чувствительностью $(0,002$ г/т) позволяет достаточно опера- 
тивно производить предварительную разбраковку наиболее перспективных участков рудных песков, как по латерали, так и в разрезе продуктивной толщи. В этой связи на первой стадии изучения рядовых проб было произведено 354 анализа исходного материала по сетке $1600 \times 1600$ м и по всему разрезу продуктивной залежи с выходом в перекрывающие и подстилающие отложения.

Результаты анализов по исходным пескам оказались намного ниже ожидаемых. Так, лишь в четырех пробах зафиксированы значения на уровне или выше порога чувствительности анализа, что казалось, вполне логичным, учитывая крайне неравномерный характер распределения золота.

Давно установленный и известный всем старателям факт потерь золота за счет прилипания мелких золотин к глинистым частицам и последующего их выноса при обогащении материала в нисходящем водном потоке поставил перед необходимостью исключить подобные потери. В этой связи с помощью СЗМ было изучено 44 пробы глинистой фракции. Выбор проб обуславливался объемом глинистой фракции в исходном материале и отбирался из проб, по которым данные СЗМ показали положительные результаты. Подобные манипуляции достаточно трудоемкие, требующие существенных затрат времени, призваны были оценить возможные потери в количественном выражении. Во всех изученных пробах глинистой фракции содержание золота оказалось ниже предела чувствительности $(<0,002$ г/т).

По данным ранее проведенных работ в фосфоритах отмечались повышенные содержания драгоценных металлов, прежде всего золота. Методом СЗМ изучено 59 проб фосфоритов (фракция $+2,5$ мм), извлеченных из рядовых керновых проб. Полученные результаты не выявили содержаний выше предела чувствительности метода. Исключение составила проба 5/191-20 (0,002 г/т).

Проведение опытно-методических работ по извлечению видимого золота на малообъемной обогатительной установке УОМ-2 из валовых проб кустовых скважин

Проектом на производство работ была предусмотрена обработка проб на установке ПОУ-4 с последующей доводкой концентрата на концентрационном столе GEMENI с целью получения гравитационнообогатимого золота. Реально была использована усовершенствованная модель УОМ-2, имеющая более высокие технологические показатели по сравнению с ПОУ-4. В отличие от ранее выпускаемой установки ПОУ-4 установка УОМ-2 обеспечивает более высокий процент извлечения полезного компонента мелких и тонких классов за счет: 1) более качественной дезинтеграции труднопромывистого материала с применением импеллерного дезинтегратора повышенной мощности и новой конструкции импеллеров; 2) более качественной классификации подрешетного продукта, благодаря применению шпальтового сита;
3) более качественного обогащения с применением модернизированных концентраторов. Установка, в соответствии с паспортными данными производителя, может применяться для сокращения и доводки концентратов, получаемых на установках для обработки крупнообъемных проб и промывочных приборах.

Установка УОМ-2 использовалась непосредственно на участке отбора проб. В процессе работ было обогащено около 27 тонн исходного материала, представленного тонкозернистыми песками, алевритами, глинистыми песками сеноманского и альбского возрастов. По промывистости (процентное содержание глинистого материала) исходный материал относится к среднепромывистой категории.

Технология обработки проб на УОМ-2 предусматривала получение следующих продуктов: 1) фракция +8 мм - губки, фосфоритизированные губки, фосфориты, песчаники; 2) фракция -8+3 мм - фосфориты, песчаники; 3) фракция -3 мм - концентрат; 4) фракция -3 мм - эфельный концентрат; 5) фракция -3 мм хвост (эфельный песок); 6) фракция -3 мм - слив.

Концентраты 27 валовых проб кустовых скважин, обогащенных на УОМ-2, дополнительно дообогащались на концентрационном столе GEMENI, после чего доводились в бромоформе (или воде) с получением супертяжелой фракции, которая визуально просматривалась на предмет обнаружения знаков золота.

Полученный тяжелый шлих был разделен на следующие гранулометрические классы: +0,2 мм, 0,2+0,071 мм; -0,071+0,063 мм; -0,063+0,05 мм; -0,05 мм. Визуально знаки золота отмечены в 17 пробах Максимальные размер выявленных золотин 0,34 мм (ед. знаки), минимальный 0,01 мм. Цвет золотин преимущественно желтый, реже темно-желтый. Форма вытянутая, угловатая, уплощенная, поверхность неровная в кавернах.

Кроме того, каждый из пяти выше указанных продуктов анализировался пробирным методом. Для анализа были отобраны пробы, для которых ранее, на предыдущих этапах работ, получены положительные результаты по спектрозолотометрическому анализу скв. 5/191, скв. 5/1465. Результаты пробирного анализа по всем типам продуктов имеют значения содержания золота $<0,2$ г/т. Это касается как эфельных продуктов, так и собственно концентрата, а также продуктов их обогащения, которые также показали результаты ниже предела обнаружения. Таким образом, установка УОМ2 золото из тонкозернистых песков экстрагирует не достаточно эффективно. Полная промывка эфельных песков на GEMENI также результатов не показала.

Проведение опьтно-методических работ по извлечению видимого золота на центробежном вибрационном концентраторе ЦВК 100-2М из валовых проб кустовых скважин

Для выявления возможной причины «утечки» золота были использованы технологии, успешно применяемые при изучении ультратонкого материала, для чего на центробежно-вибрационном концентраторе 
ЦВК 100-2М в лаборатории ОАО «ГРАНТ» г. НароФоминск были проанализированы продукты переработки песков на УОМ-2 в т.ч.: 1) материал исходной пробы, 2) эфельный песок (хвост), 3) глинистые сливы и 4) эфель из точки «боя» (слив).
В результате обогащения на ЦВК 100-2М было выявлено наличие знаков золота во всех выше указанных продуктах (табл. 1) и показало, что значительная часть золота связана с глинистым материалом и является весьма тонким и ультратонким.

Содержание знаков золота в продуктах УОМ-2 после обогащения на ЦВК 100-2М

\begin{tabular}{|c|c|c|c|c|}
\hline № пп & № пробы & Тип пробы & Вес, кг & $\begin{array}{c}\text { Количество } \\
\text { знаков золота }\end{array}$ \\
\hline 1 & В-5/191-4 & $\begin{array}{c}\text { Исходный материал по ІІІ стволу } \\
\text { кустовой скважины }\end{array}$ & $\begin{array}{c}41,70 \\
\text { (влажность 16 \%) }\end{array}$ \\
\hline 2 & В-5/191-3 & $\begin{array}{c}\text { Эфельный песок (отсечка, масса } \\
\text { всего хвоста } 185 \text { кг) }\end{array}$ & 37 (влажный) & 218 \\
\hline 3 & В-21/667-2 & Глинистая фракция (слив) & 0,806 (сухой) & 221 \\
\hline 4 & В-21/667-3 & Глинистая фракция (слив) & 0,386 (сухой) & 365 \\
\hline 5 & ХВК-1 & Материал из точки «боя» (слив) & 1,512 (влажный) & 65 \\
\hline
\end{tabular}

В соответствии с одной из задач специальных исследований (получение весового видимого золота) и положительными предварительным результатами обогащения на ЦВК 100-2М были выполнены опытно-методические работы по оптимизации процесса обогащения для тонкозернистых песков «Центрального» месторождения. Обогащение проб проводилось по следующей схеме: 1) длительная дезинтеграция песков с целью освобождения золотин от глинистой пленки; время дезинтеграции зависело от глинистости исходной пробы и продолжалось до получения пульпы «сметанообразной» консистенции, что позволяло относительно крупным песчаным частицам-активаторам (в т.ч. валунам-активаторам) более эффективно освобождать золото от глинистой пленки; 2) из репульпатора исходная проба поступала на ЦВК 100-2М через сито 2,5 мм; фракция -2,5 мм обогащалась на концентраторе; фракция $+2,5$ мм обогащалась на ЦВК 100-2М дополнительно, после высушивания и дробления до -0,1 мм. Через определенные интервалы производился съем золотосодержащего концентрата, а также автоматическая отсечка хвоста 50 гр. и дубликата хвоста 150 гр. Материал, уходящий в слив, сохранялся.

Продукты обогащения анализировались пробирным методом с атомно-адсорбционным окончанием. Решение применения атомно-адсорбционного анализа, точность которого до сотых долей, было обусловлено результатами предварительных работ: порядка 10 произвольных проб из обрабатываемой партии были изучены с помощью пробирного анализа, точность которого до 0,2 г/т. Выполненные предварительные исследования не дали положительных результатов. Полученные итоговые данные по пробирному анализу с атомно-адсорбционным окончанием показали содержание золота ниже предела чувствительности и для данного метода $(<0,01$ г/т). Исключение составили 13 проб $(0,02-0,13$ г/т), 8 из которых были проанализированы повторно для достоверности данных. Повторные результаты по- казали содержания $<0,01$ г/т. В частности, содержания более 0,01 г/т были установлены в пробах, знаки золота в которых отмечалось визуально (скв. 21/667; 5/191).

Приуроченность 13 проб к хвостам от первичного концентрата объясняется следующим обстоятельством, установленным уже непосредственно в процессе работ. Первичный концентрат весьма обогащен рудными минералами, в том числе ильменитом. При повторной обработке концентрата рифли, где накапливается концентрат в процессе обогащения, заполняются тяжелым ильменитом, который весьма сильно уплотняется, что не позволяет чешуйкам золота задерживаться в межпоровом пространстве так, как это происходило бы при обработке исходного материала с большим количеством легких минералов. Всего на ЦВК 100-2М обработано 130 хвостов после УОМ-2 и 160 проб исходного материала.

В результате сопоставления данных пробирного и пробирно-атомно-адсорбционного анализов и степени обогащения исходного материала следует, что содержание золота в продуктивных песках Центрального месторождения не превышает 0,004 г/т (табл. 2).

Для исследования гранулометрического состава продуктивных песков Восточного участка россыпи «Центральная» была изучена 351 проба по 16 скважинам, расположенным по сетке $1600 \times 1600$ м. Анализ гранулометрического состава песков и содержания золота позволил выявить следующие закономерности: 1) по латерали наиболее часто знаки золота, а также положительные результаты пробирно-атомно-адсорбционного анализа, отмечались в пробах обогащенных глинистым материалом; территориально - это продуктивные пески южной части Восточного участка месторождения (рис. 2); 2) по вертикали - знаки золота отмечались в пробах, приуроченных к верхней и нижней частям продуктивной толщи, которые содержат большое количество глинистой фракции. 
Таблица 2

Результаты сопоставления данных пробирного и пробирно-атомно-адсорбционного анализов со степенью обогащения некоторых валовых проб кустовых скважин

\begin{tabular}{|c|c|c|c|c|}
\hline $\begin{array}{c}\text { №№ } \\
\text { ПП }\end{array}$ & №№ проб & $\begin{array}{c}\text { Степень } \\
\text { обогащения }\end{array}$ & $\begin{array}{c}\text { Содержание } \mathrm{Au}, \\
\Gamma / \mathrm{T}\end{array}$ & $\begin{array}{c}\text { Содержание в исход- } \\
\text { ном материале, г/т }\end{array}$ \\
\hline 1 & B-1/309-1 & 574 & $<0,2$ & - \\
\hline 2 & B-1/309-2 & 397 & $<0,2$ & - \\
\hline 3 & B-1/309-3 & 371 & 0,20 & 0,0005 \\
\hline 4 & B-1/309-4 & 324 & $<0,2$ & - \\
\hline 5 & B-1/309-5 & 380 & $<0,2$ & - \\
\hline 6 & B-1/313-1 & 778 & 0,95 & 0,0012 \\
\hline 7 & B-1/313-2 & 341 & $<0,2$ & - \\
\hline 8 & B-1/313-3 & 410 & 0,24 & 0,0006 \\
\hline 9 & B-1/313-4 & 555 & $<0,2$ & - \\
\hline 10 & B-1/313-5 & 615 & 0,21 & 0,0003 \\
\hline 11 & B-1/313-6 & 463 & $<0,2$ & - \\
\hline 12 & B-1/313-7 & 579 & $<0,2$ & - \\
\hline 13 & B-5/1449-1 & 672 & $<0,2$ & - \\
\hline 14 & B-5/1449-2 & 516 & 0,31 & 0,0006 \\
\hline 15 & B-5/1449-3 & 516 & 0,28 & 0,0005 \\
\hline 16 & B-5/1449-4 & 492 & $<0,2$ & - \\
\hline 17 & B-5/1449-5 & 750 & $<0,2$ & - \\
\hline 18 & B-31/233-1 & 383 & $<0,2$ & - \\
\hline 19 & B-31/233-2 & 442 & 0,23 & 0,0005 \\
\hline 20 & B-31/233-3 & 446 & 0,24 & 0,0005 \\
\hline 21 & B-31/233-4 & 389 & 0,41 & 0,0011 \\
\hline 22 & B-31/233-5 & 507 & $<0,2$ & - \\
\hline 23 & B-21/137-1 & 140 & 0,62 & 0,0044 \\
\hline 24 & B-21/137-2 & 128 & $<0,2$ & - \\
\hline 25 & B-21/137-3 & 115 & $<0,2$ & - \\
\hline 26 & B-21/137-4 & 110 & $<0,2$ & - \\
\hline 27 & B-21/137-5 & 135 & 0,28 & 0,0021 \\
\hline 28 & B-21/137-6 & 123 & $<0,2$ & - \\
\hline 29 & B-21/137-7 & 140 & $<0,2$ & - \\
\hline
\end{tabular}

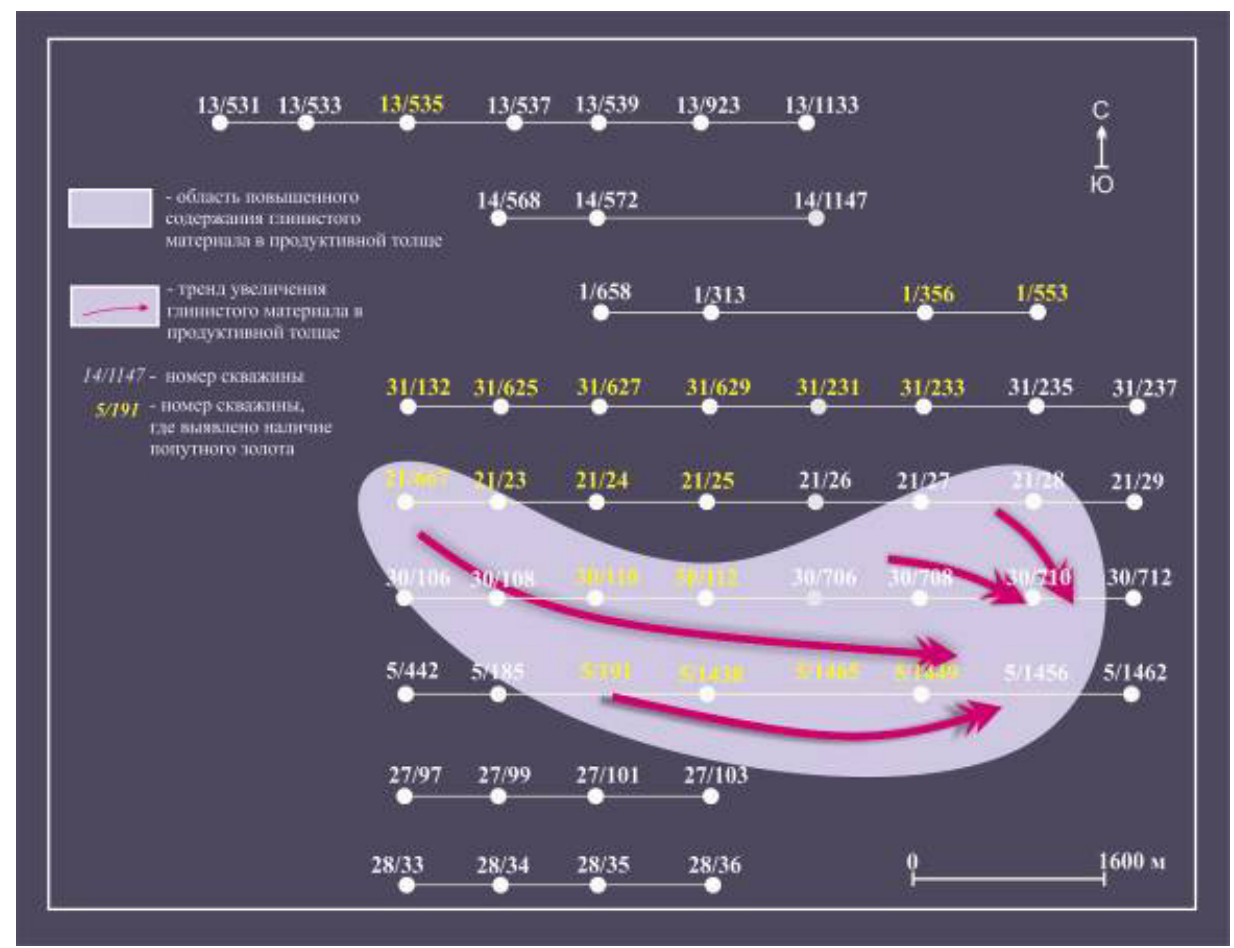

Puc. 2. Принципиальная схема увеличения содержания глинистой фракции в пределах Восточного участка Центрального месторождения. 


\section{Морфология зерен золота}

Морфология зерен золота была изучена по следующим гранулометрическим классам (мм): $-0,5+0,25 ;-$ $0,25+0,14 ;-0,14+0,1 ;-0,1+0,07 ;-0,07+0,05 ;-0,05+0,03$ и -0,03. Размеры всех зерен были измерены визуально, с помощью линейки окуляра. Результаты статистических подсчетов приводятся в табл. 3.

Таблица 3

Гранулометрический состав золота из продуктивных песков россыпи «Центральная»

\begin{tabular}{|c|c|c|c|c|}
\hline № & $\begin{array}{c}\text { Гранулометрический } \\
\text { класс, мм } \\
\end{array}$ & $\begin{array}{c}\text { Количество } \\
\text { знаков } \\
\end{array}$ & $\begin{array}{c}\text { Содержание } \\
\text { знаков, \% } \\
\end{array}$ & $\begin{array}{c}\text { Весовое } \\
\text { содержание, \% }\end{array}$ \\
\hline \multicolumn{5}{|c|}{ Проба В-5/191-4, ІІІ ствол кустовой скважиньл } \\
\hline 1 & $-0,5+0,25$ & 0 & 0,00 & 0,00 \\
\hline 2 & $-0,25+0,14$ & 3 & 1,56 & 1,32 \\
\hline 3 & $-0,14+0,1$ & 5 & 2,60 & 2,44 \\
\hline 4 & $-0,1+0,07$ & 26 & 13,54 & 21,88 \\
\hline 5 & $-0,07+0,05$ & 30 & 15,63 & 29,33 \\
\hline 6 & $-0,05+0,03$ & 123 & 64,06 & 44,91 \\
\hline 7 & $-0,03$ & 5 & 2,60 & 0,12 \\
\hline & Всего: & 192 & 100 & 100 \\
\hline \multicolumn{5}{|c|}{ Проба В-5/191-3, эфельный песок } \\
\hline 1 & $-0,5+0,25$ & 0 & 0,00 & 0,00 \\
\hline 2 & $-0,25+0,14$ & 0 & 0,00 & 0,00 \\
\hline 3 & $-0,14+0,1$ & 1 & 3,70 & 3,06 \\
\hline 4 & $-0,1+0,07$ & 3 & 11,11 & 12,51 \\
\hline 5 & $-0,07+0,05$ & 5 & 18,52 & 25,77 \\
\hline 6 & $-0,05+0,03$ & 17 & 62,96 & 58,40 \\
\hline 7 & $-0,03$ & 1 & 3,70 & 0,26 \\
\hline & Всего: & 27 & 100 & 100 \\
\hline \multicolumn{5}{|c|}{ Проба В-21/667-2, глинистая фракичия } \\
\hline 1 & $-0,5+0,25$ & 1 & 0,27 & 0,61 \\
\hline 2 & $-0,25+0,14$ & 6 & 1,64 & 4,65 \\
\hline 3 & $-0,14+0,1$ & 19 & 5,21 & 5,74 \\
\hline 4 & $-0,1+0,07$ & 50 & 13,70 & 9,88 \\
\hline 5 & $-0,07+0,05$ & 57 & 15,62 & 38,63 \\
\hline 6 & $-0,05+0,03$ & 229 & 62,74 & 40,45 \\
\hline 7 & $-0,03$ & 3 & 0,82 & 0,04 \\
\hline & Всего: & 365 & 100 & 100 \\
\hline \multicolumn{5}{|c|}{ Проба В-21/667-3, глинистая фракичия } \\
\hline 1 & $-0,5+0,25$ & 1 & 0,45 & 1,58 \\
\hline 2 & $-0,25+0,14$ & 18 & 8,14 & 10,61 \\
\hline 3 & $-0,14+0,1$ & 20 & 9,05 & 13,65 \\
\hline 4 & $-0,1+0,07$ & 50 & 22,62 & 34,48 \\
\hline 5 & $-0,07+0,05$ & 29 & 13,12 & 17,90 \\
\hline 6 & $-0,05+0,03$ & 102 & 46,15 & 21,76 \\
\hline 7 & $-0,03$ & 1 & 0,45 & 0,02 \\
\hline & Всего: & 221 & 100 & 100 \\
\hline \multicolumn{5}{|c|}{ Точка боя } \\
\hline 1 & $-0,5+0,25$ & 0 & 0,00 & 0,00 \\
\hline 2 & $-0,25+0,14$ & 0 & 0,00 & 0,00 \\
\hline 3 & $-0,14+0,1$ & 1 & 1,54 & 1,52 \\
\hline 4 & $-0,1+0,07$ & 7 & 10,77 & 6,55 \\
\hline 6 & $-0,07+0,05$ & 10 & 15,38 & 5,50 \\
\hline 7 & $-0,05+0,03$ & 47 & 72,31 & 86,42 \\
\hline \multirow[t]{2}{*}{8} & $-0,03$ & 0 & 0,00 & 0,00 \\
\hline & Всего: & 65 & 100 & 100 \\
\hline
\end{tabular}


Из анализа таблицы видно, что более крупные фракции характерны для золота из слива, которое уносится за счет глинистой рубашки. Следует отметить, что самое значительное количество знаков во всех изученных пробах приходится на фракцию $0,05+0,03$ мм.

Для исходного песка (проба номер B-5/191-4(III)) наиболее характерные гранулометрические размеры золота приходятся на классы -0,1 мм, с преобладанием (как в количественном по знакам, так и в весовом отношении) размерности -0,05+0,03 мм. Для хвостов соотношение различных гранулометрических классов несколько меняется. Так, в хвосте пробы В-21/667-2 наибольшее количество знаков сосредоточено в клас-

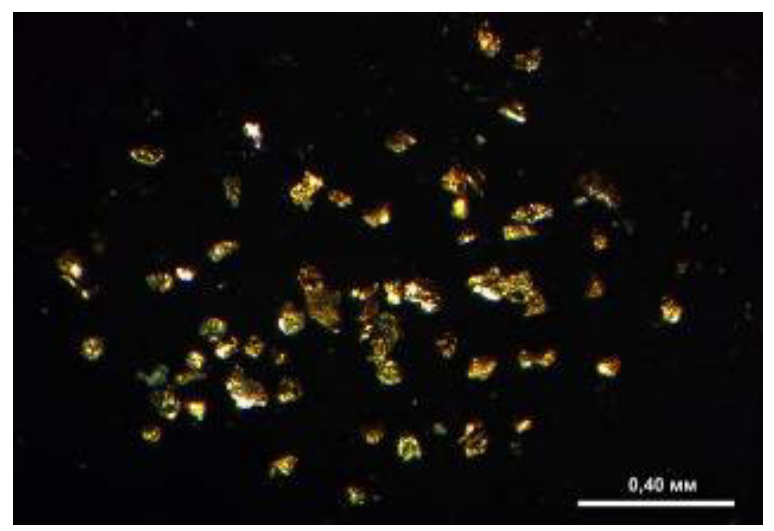

Проба В-5/191-4, ІІІ ствол кустовой скважины

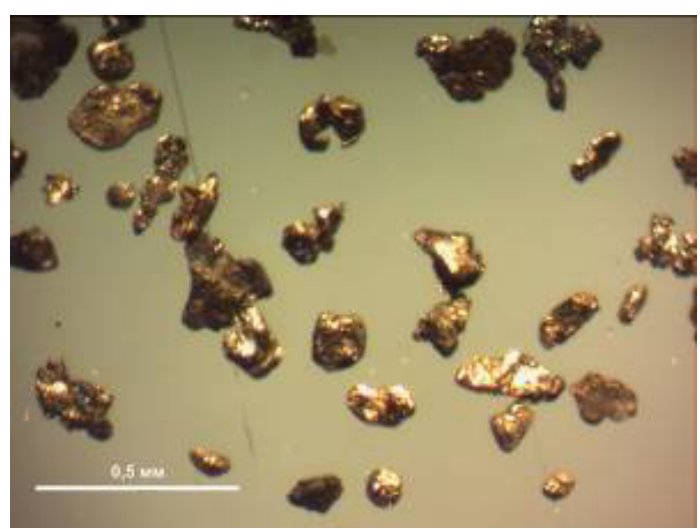

Проба В-21/667-3, глинистая фракция

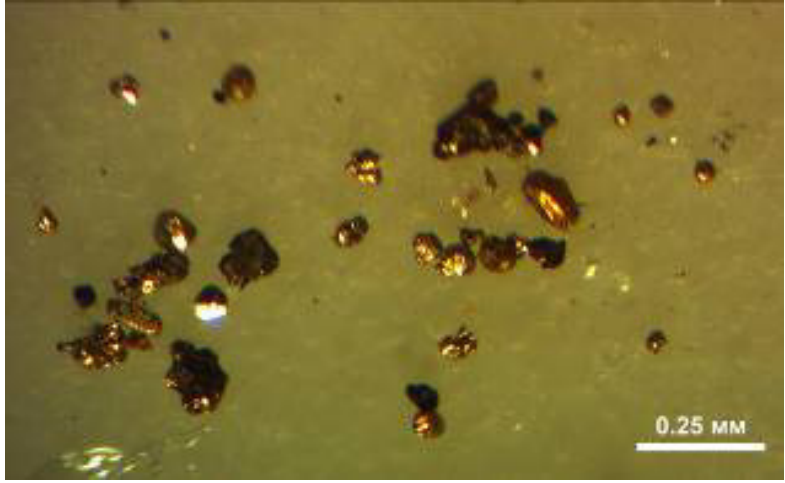

Проба В-21/667-2, глинистая фракция cax 0,07-0,05 мм и -0,05+0,03 мм (57 знаков - 38,63 вес. \% и 229 знаков - 40,45 вес. \% соответственно); для хвоста пробы В-2/667-3 характерно увеличение весовых долей более крупных классов с пиком по весовым процентам приходящимся на фракцию 0,1+0,07 мм, при сохранении количественного по знакам преобладания фракции -0,05+0,03 мм.

Морфология золота в изученных пробах крайне разнообразна и существенно различается для разных гранулометрических классов (рис. 3). Окатанность зерен варьируется от отсутствующей до значительной. Для мелкого золота из классов менее 0,1 мм характерны, главным образом, умеренно и сильно окатанные сферические и эллипсоидальные зерна. Среди

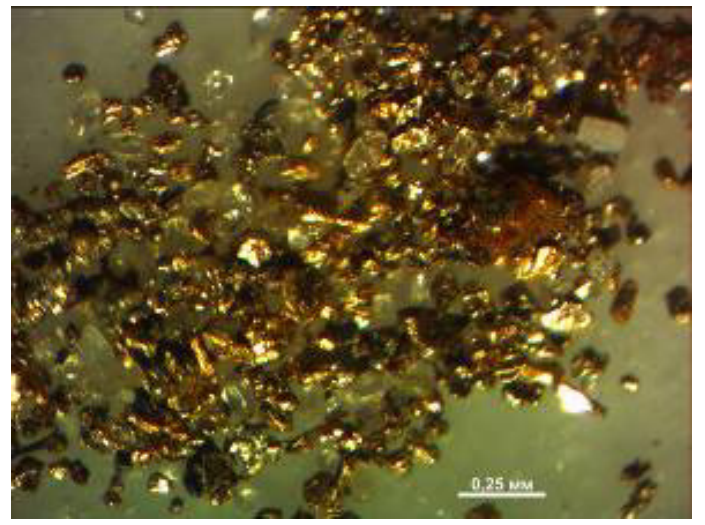

Проба В-5/191-3, эфельный песок

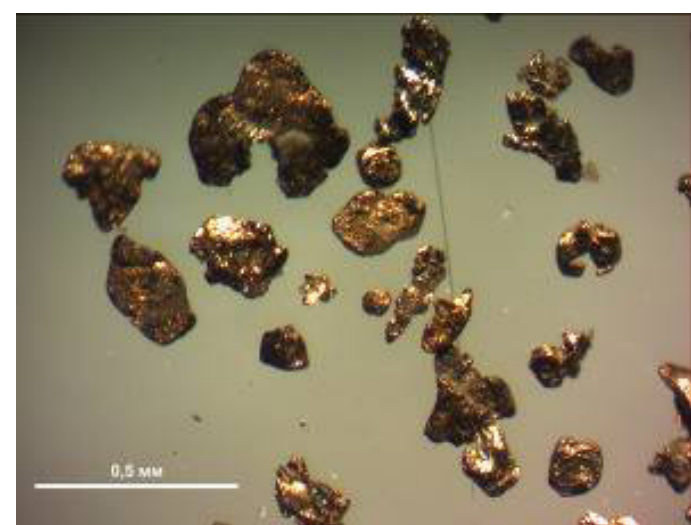

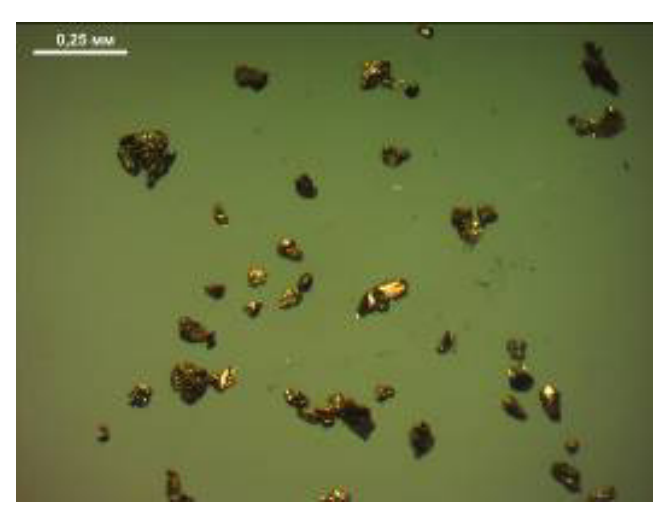

Точка боя

Puc.3. Частицы золота их продуктивных песков месторождения «Центральное». 
частиц крупнее 0,1 мм распространены слабо окатанные, уплощенные разновидности (пластинчато-таблитчатые, тонкопластинчатые, удлиненно-таблитчатые), реже встречаются зерна изометричных очертаний, а также дендритовидные, игольчатые, амебовидные, стружковидные агрегаты. Возможно, такая форма может свидетельствовать об их эксгаляционноосадочном генезисе, как это показано в работах [11, 12]. Внешние контуры многих зерен неровные, извилистые, отмечаются углубления, иногда загнутые выступы. Поверхность золотин варьирует от грубоячеистой до шагреневой. Тонкие пластинки и относительно крупные частицы иногда несут следы транспортировки в виде смятия, изгибов, рваных краев. Зерна имеют ярко-желтый цвет, что характерно для высокопробного золота, изредка встречаются бледно-желтые зерна с серебристым отливом и желтые со слабым красноватым оттенком.

Во многих случаях отмечаются пленки гидроксидов железа красновато-бурых и бурых тонов, особенно характерные для углублений в корродированной поверхности золотин. Наличие тончайшей пленки свидетельствует о слабом воздействии на транспортируемые зерна, что, скорее всего, связано с их длительной консервацией глинистыми частицами. Чешуйки такого типа наиболее характерны для проб, отобранных из слива.

\section{Заключение}

В результате проведенных исследований можно сделать следующие выводы:

1) Не смотря на подтвержденную широкую «зараженность» золотом продуктивных песков титан-циркониевой толщи месторождения «Центральное», характер распределения золота крайне неравномерный, а его максимальные содержание незначительны. По данным СЗМ-анализа в рядовых пробах содержания золота редко превышают предел чувствительности $(0,002$ г/т) как в исходных песках, так и в глинистой фракции.

2) Золото из продуктивных песков титан-циркониевой россыпи «Центральная» характеризуется тонкими (до 0,1 мм) и ультратонкими (<0,1 мм) размерами и присутствием глинистого материала, выступающего в качестве консерватора. Характерно, что наиболее крупные чешуйки золота имеют тонкую пленку, свидетельствующую об их консервации от механического воздействия в процессе переноса, а таким «консерватором» служит глинистый материал. Для более мелких и тонких классов отмечается высокая очищенность золота. Наиболее часто знаки золота отмечаются в продуктивных песках с относительно высоким содержанием глинистой фракции.

3) Попытка извлечения тонкого и ультратонкого

Воронежский государственный университет

Бондаренко Светлана Владимировна, дочент кафедры обмеей геологии и геодинамики, к. г.-м. н.

E-mail: sw_bondarenko@hotmail.com; Tел.: +7(473)2208926

Золотарева Галина Сергеевна, дочент кафедры общей геологии и геодинамики, к.г.-м.н.E-mail: akcessoriy@mail.ru золота с высокой степенью концентрации исходного материала была произведена из 130 хвостов проб кустовых скважин и 160 исходных проб кустовых скважин на специализированной установке ЦВК 100-2М с визуальным просмотром и контролем пробирно-атомно-адсорбционным анализом. Обнадеживающих результатов не получено из-за низких содержаний золота в исходном материале - содержание золота в продуктах обогащения менее порога чувствительности $(0,01$ г/т).

На основании проведенных работ напрашивается общий вывод о невысоких перспективах попутного извлечения золота из титан-циркониевых песков из-за крайне низких его содержаний и плохой извлекаемости гравитационными методами.

\section{ЛИТЕРАТУРА}

1. Беневольский Б. И. Минерально-сырьевая база золота на рубеже XXI в. / Б. И. Беневольский, В. Н. Иванов // Минеральные ресурсы России. Экономика и управление. М., 1999. - № 1. - С. $9-16$.

2. Перспективы комплексного использования титано-циркониевых россыпных месторождений России / Л. 3. Быховский [и др.] // Горный журнал. - 1997. - № 8. - С. 22-26.

3. О проблеме попутного получения золота из нетрадиционных источников / Л. З. Быховский [и др.] // Минеральные ресурсы России. - 1999. - № 6. - С. 35-39.

4. Северный Кавказ - перспективная для промышленного освоения титан-цирконовая провинция России / Л. И. Веремеева [и др.] // Разведка и охрана недр - 2004. - № 3. - С. 5-15.

5. Попутное золото в титан-циркониевых россыпях Ставропольского россыпного района - фактор повышения их инвестиционной привлекательности / Л. И. Веремеева [и др.] // Разведка и охрана недр. - 2014. - № 9. - С. 35-41.

6. Итоговый доклад «О результатах и основных направлениях деятельности Роснедр за 2015 год и задачах на 2016 год» - [Электронный pecypc]. - Режим доступа: http://www.rosnedra. gov.ru/article/8472.html - (Дата обращения: 24.05.2017)

7. Карта полезных ископаемых Тамбовской области. Масштаб 1:500 000 / под ред. А. А. Ширшова, 1998 г.

8. Левченко, E. H. Научно-методическое обоснование минералого-технологической оценки редкометалльно-титановых россыпей / Е. Н. Левченко // автореф. на соиск. уч. степ. Д.г.-м.н.. М.: ФГУП ИМГРЭ, 2011. $-41 \mathrm{c.}$

9. Минприроды России намерено разрешить попутную добычу полезных ископаемых при освоении недропользователями многокомпонентных месторождений - [Электронный ресурс]. Режим доступа: http://www.mnr.gov.ru/news/detail.php?ID= 143294 - (Дата обращения: 24.05.2017 г.)

10. Петровская, Н. В. Самородное золото. / Н. В. Петровская // М.: Недра, 1973. -375 с.

11. Савко, А. Д. Эксгаляционно-осадочная металлоносность Воронежской антеклизы - новые горизонты поисков рудных месторождений в осадочном чехле. Статья 1. Интерметаллиды : локализация, типы, состав / А. Д. Савко, Л. Т. Шевырев, В. В. Лоскутов // Вестн. Воронеж. гос. ун-та. - 1999. - Сер. геол. - № 7. - С. 139-155. 12. Савко, А. Д. Ультратонкое золото / А. Д. Савко, Л. Т. Шевырев // Труды научно.-исследовательского. института геологии Воронеж. гос. ун-та. - 2001. Вып. 6. - 151 с.

Voronezh State University

Bondarenko S. V., lecturer of General Geology and Geodynamics Department, Candidate of Geological and Mineralogical

Sciences.E-mail: sw_bondarenko@hotmail.com

Zolotareva G. S., lecturer of General Geology and Geodynamics Department, Candidate of Geological and Mineralogical Sciences.E-mail:akcessoriy@mail.ru; Tel.: +7 (473) 2208926 